\title{
Application of The Theory of Essentialism Philosophy Problems in Mathematics Literacy for Junior High School Students
}

\author{
$1^{\text {st }}$ Krisni Suhardiyani $\left.^{1}{ }^{\bowtie}\right), 2^{\text {nd }}$ Laila Fitriana, ${ }^{2}$ \\ ${ }^{1,2}$ Postgraduate of Mathematics Education, Faculty of Teacher Training and Education, Universitas Sebelas Maret, Surakarta, \\ Indonesia \\ Corresponding author. Email: krisnisuhardiyaniestudent.uns.ac.id
}

Accepted: Mey 25 , 2021

Approved: June 30, 2021

Published: July 25, 2021

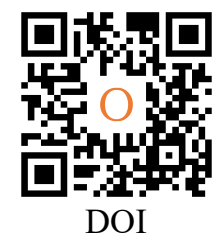

Publisher: El Syits Project
Abstract - The purpose of this research is to find out what are the mathematics literacy problems of SMP N 2 Surakarta students and find out how to apply essentialism theory to these problems. This research uses qualitative research methods and literature study. Data collection using task-based interviews. Data collection in this study was carried out in class 9E of SMP Negeri 2 Surakarta. Subjects were taken randomly (simple random sampling) from as many as two students. The conclusions of this research are: (1) levels 1 and 2 partially fulfill and level 3 does not meet, the cause of the problem from not achieving mathematical literacy levels 1 to 3, namely, teachers are limited in delivering material and students cannot receive maximum understanding of the material, learning only one direction from the teacher, there are still students who do not have an awareness of responsibility for learning obligations and learning motivation is still low, many students have forgotten the materials at the previous level and the teacher does not always give apperception, the teacher does not provide an understanding of the concept, but directly give formulas and calculations, and teachers rarely give story questions to students; (2) with the application of essentialism theory in mathematical literacy problems, several things can be done, namely: first, the use of learning strategies to attract students' interest in reading and writing; second, improve the quality and equity of education; third, the government needs to prioritize teaching basic skills such as reading, writing, and mathematics; fourth, the application of ethnomathematics-based learning; fifth, education should synergize the three intelligences (IQ, EQ, SQ) in the learning process.

Keywords - Essentialism, Mathematics Literacy, PISA

\section{INTRODUCTION}

Education is one of the most important things in improving human resources. The human resources of a nation will affect the progress of the nation's civilization. The higher the human resources, the more advanced the civilization of his people. Education occurs in all aspects, cultural, social, political economy, etc. Every level of education ranging from kindergarten, elementary, junior high, high school / vocational school, and PT (Higher Education) that gets the learning process is an education.

One of the fields of study that always exists at every level of formal education is mathematics. Sholihah \& Mahmudi (1) stated that the field of science that has an important role in the world of education and to deal with life problems is mathematics. Given the importance of the role of mathematics education so that mathematics education must develop in a positive direction.

The definition of literacy can simply be described as the ability to read and write, and count (2). Abidin, Mulyati \& Yunansah (3) defines literacy as the skill in stating and understanding information, using text, symbols and multimedia. While math literacy is the ability to understand, apply mathematics to a context in the process of solving problems, and be able to explain to others how to use mathematics (3).

One of the international assessments is PISA (Program for International Student Assessment) which is held once every three years to find out the literacy skills of 15-year-old students in reading literacy, math literacy, and science literacy (4). Pisa results in 2018, Indonesia only obtained a score of 379 for mathematical literacy, while the average 
Ordinal: Innovation in Research, Development, and Learning on Mathematics Education Journal Doi:

was set at 489. Mahdiansyah and Rahmawati (5) also stated that the mathematical literacy of Indonesian students is still not satisfactory. (6)

The low literacy of students in Indonesia should be something that must be considered by the government. Indonesia must take remedial action in terms of education. Actions that are able to improve the quality of education in Indonesia are getting better. Basic things that need to be applied in education in Indonesia, one of which is to apply the theory of essentialism.

Essentialism is an educational theory that wants the foundation used in the education system to be essential. These essential things are time-tested, guiding, and have been hereditary from time to age (7). Furthermore, Hafid (7) states that Essentialism requires that the foundation of education is rooted in essential values, namely those that have been tested by time, are guiding and have been hereditary from time to time. The view of essentialism seeks to emphasize basic education with basic skills of reading, writing, and numeracy. This school also puts forward past cultures that have been tested for efficacy to be reapplied in the education system. Therefore, in this study the author wanted to know what are the problems of mathematics literacy of junior high school students N 2 Surakarta and how the application of essentialism theory in the problem.

\section{RESEARCH METHOD}

This research uses qualitative research methods and literature studies. Mathematical literacy retrieval using taskbased interviews. The collection of mathematical literacy data in this study was conducted in the 9E class of SMP Negeri 2 Surakarta. Subjects were taken randomly (simple random sampling) from as many as two students, obtained one male student and one female student.

\section{RESULTS AND DISCUSSIONS}

Based on the analysis of test results and interviews, each subject data on mathematical literacy skills can be presented in the following table:

Table. 1. Results of Mathematical Literacy Skills

\begin{tabular}{|l|l|l|}
\hline No. & \multicolumn{1}{|c|}{ Subject } & \multicolumn{1}{|c|}{ Data } \\
\hline 1. & $\begin{array}{l}\text { Subject 1 } \\
\left(\mathrm{S}_{1}\right)\end{array}$ & $\begin{array}{l}\text { Level 1: } \\
\text { Subject 1 meets part of level 1, because subject 1 can understand the question } \\
\text { with a known context and can collect information, namely grocery items in the } \\
\text { form of building space, its definition, and the extent of building space, although } \\
\text { there is still information that is not yet known, namely the area and definition of } \\
\text { the ball and can solve the problem clearly that makes the frame build space, but } \\
\text { still not right on the ball. } \\
\text { Level 2: } \\
\text { Subject 1 meets some level 2, because she/he is able to interpret and recognize } \\
\text { the situation in the problem that is about the comparison of pizza 1 and pizza 2 } \\
\text { and can use formulas and conclude, but the use of formulas and how to conclude } \\
\text { them is still not appropriate. } \\
\text { Level 3: } \\
\text { Subject 1 does not meet level 3, because she/he has not been able to carry out } \\
\text { procedures and choose and implement strategies in resolving problems, has not } \\
\text { been able to interpret and represent the situation. }\end{array}$ \\
\hline Level 1: \\
$\begin{array}{l}\text { Subject 2 meets part of level 1, because she/he can understand questions with } \\
\text { known context and can collect information, namely grocery items in the form of } \\
\text { building space, definition, and the extent of building space, although there is still }\end{array}$ \\
\hline $\begin{array}{l}\text { Subject 2 } \\
\left.\mathrm{S}_{2}\right)\end{array}$
\end{tabular}




\begin{tabular}{|l|l|}
\hline $\begin{array}{l}\text { information conveyed is not appropriate. Unable to solve the problem clearly is } \\
\text { to make the framework build space. } \\
\text { Level 2: } \\
\text { Subject } 2 \text { meets some level 2, because she/he is able to interpret and recognize } \\
\text { the situation in the problem that is about the comparison of pizza } 1 \text { and pizza } 2, \\
\text { and can use formulas and conclude, but the use of formulas and how to conclude } \\
\text { them is still not appropriate. } \\
\text { Level 3: } \\
\text { Subject } 2 \text { does not meet level 3, because she/he cannot carry out procedures } \\
\text { and choose and implement strategies in resolving problems. Unable to interpret } \\
\text { the situation in resolving the problem due to the implementation and selection of } \\
\text { inappropriate procedures. }\end{array}$ \\
\end{tabular}

From the results of the analysis, students' math literacy problems, namely from the three levels of math literacy, subject 1 and subject 2 meet partly for levels one and two, while level three does not meet.

Based on the interview of the $9 \mathrm{E}$ class teacher, the following causes of math literacy problems of junior high school students N 2 Surakarta: (1) mathematics learning conducted online causes limited space between teachers and students, teachers are limited in the delivery of materials and students cannot receive maximum understanding of the material, emotional relationships between teachers and students are also not well awakened; (2) mathematics learning carried out online causes learning only one way from the teacher, this makes the learning goal is not achieved to the maximum, let alone the independence of students' learning is still low; (3) there are still students who do not have a responsibility awareness of learning obligations, student learning motivation is still low, students do not respond actively when learning mathematics online or Face-to-Face Meetings (PTM) which has now begun to be held once a week; (4) Many students who have forgotten the materials at the previous level, the teacher also does not always give a perception before starting new material; (5) When describing a material, such as the volume of a cube, the teacher does not give an understanding of the concept, but immediately gives the formula and the way it is calculated. This makes students not understand the concept well; (6) At the time of learning, the teacher only emphasizes the problem of calculations, teachers rarely give questions to students because students have a lot of difficulty in the story, the teacher also never discusses hots at the time of learning, for fundamental reasons only students do not try much.

One of the actions that can be done to overcome the problem of mathematical literacy is to apply the theory of essentialism to education. Essentialism is an educational theory that wants the foundation used in the education system to be essential. These essential things are time-tested, guiding, and have been hereditary from time to age (7). Furthermore, Hafid (7) states that essentialism requires that the foundation of education is rooted in essential values, namely those that have been tested by time, are guiding, and have been hereditary from time to time.

Essentialism as one of the theories of education offers a variety of views in restoring the true essence of education. The first of basic subjects such as reading, writing, and mathematics is believed to be the basic capital for students towards their future. This theory also emphasizes the importance of education based on something that has been tested for its efficacy, namely culture in the past. This stream also criticizes the curriculum developed with the nature of flexibility. A curriculum structured with a principle of flexibility is seen to be an easy and erratic basis. According to essentialists, a volatile educational curriculum will become easily shaky and inconsistent. This theory assumes that the best thing that should be used as a foundation in education is to return to the old culture that has been tested for existence. There are several advantages to the theory of essentialism, namely: (1) it helps to restore subject matter to the educational process and (2) change is an irreversible reality in social life (8).

There are several things that are the principles of the philosophy of essentialism, namely: (1) education must emphasize the importance of discipline, (2) initiatives in education must be owned by teachers rather than students, (3) the core of the educational process is the assimilation of the subject matter that has been determined, (4) schools must maintain traditional methods related to mental discipline, and (5) the ultimate goal of education is to improve the general well-being (9).

The application of essentialism theory in mathematical literacy problems is, first, the use of learning strategies to attract reading interest for learners, one of which is by using a literature basedmodel. This model is a form of whole 
Ordinal: Innovation in Research, Development, and Learning on Mathematics Education Journal Doi:

language approach that seeks to integrate listening, speaking, reading and writing skills (10). Second,improving the quality and equitable distribution of education to encourage literacy levels in Indonesia, build more libraries throughout the region, implement sustainable programs to increase reading-writing interest, encourage publishers to publish more books, and synergize between communities, institutions, and governments in building a civilization of reading and writing (11). Third, the government needs to prioritize teaching on basic skills such as reading, writing, and mathematics. It would be better if starting from the elementary school level, students have been introduced to the culture of reading ranging from reading classical literature to popular writings. For example, the government can implement a policy related to reading activities with half a day of reading and not bound only 15 minutes before lesson hours begin (12). Fourth,the application of ethnomamatic-based learning. Research conducted by Laurens (13) on ethnomamatic analysis and its application in improving the quality of learning shows that some mathematical concepts taught through Maluku culture can be used to understand the concepts of numbers, fractions and geometry. Research Muhtadi, Sukirwan, Warsito, \& Prahmana (14) revealed that the ethnoatematics of Sundanese culture is related to estimating, measuring, and making patterns. Other researchers $(15 ; 16 ; 17)$ stated the existence of mathematics in the culture of the community. A superior nation is a nation that has cultural intelligence characterized by the ability to manage the virtues of tradition. Cultural intelligence does not mean carrying the old culture to be applied to the present, but managing old cultural values as national assets (18). Fifth, education should synergize three intelligences in the learning process, namely intelligence intelligence (IQ), emotional intelligence ((EQ), and spiritual intelligence (SQ). If all three intelligences are managed properly then it will potentially build social intelligence (SocQ). Social intelligence is important in fortifying itself against the changes and onslaught of destructive external cultures. In essence, in the education curriculum should be based on the culture of the nation (12).

\section{CONCLUSIONS AND SUGGESTIONS}

The conclusion of this research is: (1) the mathematical literacy of junior high school students N 2 Surakarta has not been met at levels 1 and 2, while level 3 is not fulfilled. Students cannot achieve math literacy level 1 to 3 due to teachers being limited in the delivery of materials, and students cannot receive maximum material understanding, learning is only one way from teachers. There are still students who do not have a responsibility awareness of the obligations of learning and learning motivation that is still low, many students who have forgotten the materials at the previous level and teachers do not always give understanding, teachers do not give understanding of the concept, but directly give formulas and ways of calculation, and teachers rarely give stories to students; (2) with the application of essentialism theory in mathematical literacy problems can be done several things, namely: first, the use of learning strategies to attract reading interest for learners; second, improving the quality and equitable distribution of education; third, the government needs to prioritize teaching on basic skills such as reading, writing, and mathematics; fourth, the application of learning based on ethnomathematics; fifth, education should synergize three intelligences (IQ, EQ, $\mathrm{SQ}$ ) in the learning process.

Advice as a follow-up to this study is a study that states that the mathematical literacy skills of middle school students who meet partly at levels 1 and 2, and level 3 that do not meet, can be used as a basis for making the development of teaching materials or learning models to improve students' mathematical literacy skills with elements of essentialism theory'

\section{REFERENCES}

[1] Sholihah, D. A., \& Mahmudi, A. (2015). Keefektifan Experimental Learning Pembelajaran Matematika MTs Materi Bangun Ruang Sisi Datar. RISET PENDIDIKAN MATEMATIKA, 175-185.

[2] UNESCO. (2006, March). Dipetik Oktober 9, 2021, dari Literacy Initiative for Empowerment: https://unesdoc.unesco.org/ark:/48223/pf0000141177

[3] Abidin, Y., Mulyati, T., \& Yunansah, H. (2017). Pembelajaran Literasi Strategi Meningkatkan Kemampuan Literasi Matematika Sains, Membaca dan Menulis. Jakarta: Bumi Aksara.

[4] OECD. (2010, July 9). Dipetik Oktober 9, 2021, dari Education at a Glance 2010: OECD Indicators: http://www.oecd.org/education/skillsbeyondschool/educationataglance2010oecdindicators.htm

[5] Mahdiansyah, \& Rahmawati. (2014). Literasi Matematika Siswa Pendidikan Menengah: Analisis Menggunakan Desain Tes Internasional dengan Konteks Indonesia. Jurnal Pendidikan dan Kebudayaan, 20(4), 452-469.

[6] OECD. (2019, December 3). PISA 2018 Result. Dipetik Oktober 9, 2021, dari https://www.oecd.org/pisa/publications/pisa2018-results.htm

[7] Hafid, S. A. (2015). Pemikiran Esensialisme, Eksistensialisme, Perenialisme, dan Pragmatisme dalam Perspektif Pendidikan Islam. Jurnal al-Asas, 3(1), 165-178.

[8] Thaib, M. I. (2015). Esensialisme dalam Perspektif Filsafat Pendidikan Islam. Jurnal Mudarrisuna, 4(2), 731-762. 
Krisni Suhardiyani \& Laila Fitriana , Application of The Theory of Essentialism ...

[9] Abas, E. (2015). Asas Filosofi Teori Belajar Esensialisme dan Implikasinya dalam Pembelajaran. Jurnal Lentera, 2, $103-120$.

[10] Silvia, O. W., \& Djuanda, D. (2017). Model Literature Based dalam Program gerakan Literasi sekolah. Jurnal Mimbar Sekolah Dasar, 4(2), 160- 171.

[11] Permatasari, A. (2015). Membangun Kualitas Bangsa dengan Budaya Literasi (hlm. 146-156). Dipresentasikan pada Seminar Nasional Bulan Bahasa 2015, Bengkulu: Universitas Bengkulu.

[12] Helaluddin. (2018). Restrukturisasi Pendidikan Berbasis Budaya: Penerapan Teori Esensialisme di Indonesia: Jurnal Dimensi Pendidikan dan Pembelajaran Universitas Muhammadiyah Ponorogo, 6(2), 74-82.

[13] Laurens, T. (2016). Analisis Etnomatematika dan Penerapannya dalam Meningkatkan Kualitas Pembelajaran. Lemma, 3(1), 86-96.

[14] Muhtadi, D., Sukirwan, Warsito, \& Prahmana, R. C. I. (2017). Sundanese Ethnomathematics: Mathematical Activities in Estimating, Measuring, and Making Patterns. Journal on Mathematics Education, 8(2), 185-198.

[15] Abdullah, A. S. (2017). Ethnomathematics in Perspective of Sundanese culture. Journal on Mathematics Education, 8(1), 116.

[16] Supiyati, S., Hanum, F., \& Jailani. (2019). Ethnomathematics in Sasaknese Architecture. Journal on Mathematics Education, 10(1), 47-57.

[17] Utami, N. W., Sayuti, S. A., \& Jailani. (2019). Math and Mate In Javanese Primbon: Ethnomathematics Study. Journal on Mathematics Education, 10(3), 341-356.

[18] Karsidi, R. (2017). Pendidikan Berbasis Budaya menuju Keunggulan Bangsa (hlm. 1-17). Dipresentasikan pada Seminar International Character Development in the 21st Century Education, Yogyakarta: Universitas PGRI Yogyakarta.

\section{AUTHORS}

$\mathbf{1}^{\text {st }}$ Krisni Suhardiyaniis a Postgraduate of Mathematics Education, Faculty of Teacher Training and Education, Universitas Sebelas Maret, Surakarta, Indonesia, (krisnisuhardiyani@ student.uns.ac.id)

$2^{\text {nd }}$ Laila Fitriana is Postgraduate of Mathematics Education, Faculty of Teacher Training and Education, Universitas Sebelas Maret, Surakarta, Indonesia (lailafitriana_fkip@staff.uns.ac.id) 